between the acts of the " surgeon" and those of the "assistantsurgeon"- the former having taken, the latter having as yet to take, the oath at the College of Surgeons, which should impose upon its members the duty of "upholding the dignity of the profession." With many thanks for your laudable exertions in the crusade against quackery, $I$ remain, your very obedient servant,

New-road, Apil, 1849.

\section{[THE CARD.]}

"Nedical Institution, or Private Dispensary, 31, St. Pancrasplace, Olel St. Pancras-road.-Hours of consultation, from twelve to two in the afternoon, and from seven to nine in the evening.-A fee of one shilling is charged for consultation.No extra charge will be made for medicines, minor operations of surgery, or any appliances necessary. This institution is established to meet the requirements of the middle and working classes; to afford the best medical and surgical advice and medicines for a small fee.-N.B. Patients are visited at their own residences for a small fee, regulated according to the distance, or the circumstances of patients."

[THE CIRCULAR.]

"Somers Toun Self-supporting Dispensary, 31, St. Pancrasplace, Old Pancras road.-Medical officers: Surgeon, M. W. Hilles, Esq., Lecturer on Anatomy, Surgery, \&c.; Assistantsurgeon, Mr. West Ford; Dispenser, MIr. Parker--Hours of consultation, from twelve to two in the morning, and from seven to nine in the evening.-A fixed fee of one shilling for each consultation. No extra charge will be made for medicines, minor operations of surgery, or any appliances necessary.-As good food is essential to health, so good advice and good medicines are necessary to the body whilst afflicted with illness. Many serious attacks of sickness might be prevented, if the individual affected had the means of obtaining these in time. At present, these are not within the reach of many persons in the middle and humbler walks of life, because-1st. They cannot afford to pay the charge usually made for good professional attendance, \&c. 2ndly. Their feelings recoil from being indebted to the hand of charity for relief. 3rdly. The loss of time experienced at charitable institutions is more serious to them than even the outlay of money. The consequence is, that they are obliged to resort to the quack, or impostor, for assistance, and too often suffer, in their laudable desire to obtain health, and study economy. The Somers Town Self-supporting Dispensary is established to meet the wants of these classes, and will afford-1st. The best professional advice in all cases of illness. 2ndly. The best medicines as procured from Apothecaries' Hall. 3rdly. The best surgical aid in cases of accident or diseases requiring operations of a minor character. By the establishment of this institution, the respectable tradesman, mechanic, or working man, may receive every possible assistance necessary in all cases of illness, at an expense which he can afford, without contracting debts or otherwise exposing himself to difficulties which too frequently prove greater than he is afterwards able to meet.- No letter of recommendation is required."

\section{EXTRAORDINARY PROCEEDINGS UNDER TIIE APOTHECARIES' ACT. \\ To the Editor of The LANCET.}

SIR,-Wo take the liberty of forwarding to you the enclosed circular, a copy of which has been received by each of the persons whose names are published in it, and numerous copies are posted on the walls in the neighbourhood.

We trust you will allow us a place in your valuable journal, that we may take the sense of the profession generally, on what appears to us an unmanly and a cowardly attempt to deprive us of a position to which we consider ourselves fairly entitled.

You will observe that this paper is headed with the royal arms; ends with "God save the Queen;" and is evidently intended to bear the semblance of an official document.

It is, however, without the printer's name, and is therefore circulated contrary to law.

We deem it necessary to state, that we (Mr. Latham and Mr. Rolph) are both members of the Royal College of Surgeons, of Eugland; and have both completed the course of study prescribed by the Society of A pothecaries, intending to present ourselves there for examination, as soon as convenient.

Under these circumstances, we appeal to you as a public journalist, who have the true interests of the profession at heart; we trust you will allow us, through you, to appeal to the whole body of the profession; we even appeal to the Society of Apothecaries themselves, to say whether they justify the authors of such an outrage as this on members of a body standing so high in the profession as the Cullege of Surgeons.

We ask you and them," Does the mere fact of our not being apothecaries deprive us of all right and title to professional courtesy and gentlemanly treatment?"'

Is this a sufficient excuse for posting us at the streetcorners as illegal practitioners, and setting a price upon our heads as felons?

Did the Society of Apothecaries themselves, in any instance, even when proceeding against men without any qualification whatever, ever resort to such a dastardly proceeding as this ; and will they justify it now?

We flatter ourselves that you and they will be unanimous in sconting such a villanous attack; and that you will, with us, denounce it as disgraceful to any man or body of men belonging to a liberal (?) profession, and styling themselves gentlemen.

We have forwarded a copy of the circular to the Society of Apothecaries to know whether it has been printed and distributed with their cognizance or authority.

We sincerely hope that you will give us your valuable as. sistance in laying this matter before the profession,-and we are, Sir, your obedient servants,

JAMES ROLPH, M.R.C.S.E., 197, Bethnal-Green-road

Charles Willum Latham, M.R.C.S.E

April, 1818. 56, Chureh-street, Bethnal-Green-road.

[COPY OF THE LARGE POSTING BILL.]

"Twenty Pounds Penalty and Imprisonment.-Illegal Medical Practice.-Whereas, by an Act passed in the 53rd year of the reign of our Sovereign Lord King George the Third, entitled, 'An Act for the better regulating the Practice of Apothecaries throughout England and WWales,' it is specially mentioned: That whereas much mischief has arisen from great numbers of persons in many parts of England and Wales exercising the functions of an apothecary, who are wholly ignorant and utterly incompetent to the exercise of such functions, whereby the health and lives of the community are greatly endangered. And be it further enacted, That if any person, not being qualified under this Act, do practice [practise] as an apothecary, every person so offending, shall for every such offence, forfeit and pay the sum of twenty pounds. And it is further enacted, That no person acting as an apothecary, unless qualified under this Act, shall be allowed to recover any charges claimed by him in any court of law. And whereas by and with the advice of counsel learned in the law, the Society of A pothecaries can proceed by indictment against any person so offending, and her Majesty's judges can at their discretion inflict fine or imprisonment. Notice is hereby given, that the following parties are not licentiates of the Society of Apothecaries:-Mr. J. Rolph, 197, Bethnal Green-road; Mr. Baker, Wilmot-square, Bethnal Green-road; Mr. C. Welch, Dog.row, Bethnal Green; Mr. Latham, Churchstreet; $\mathrm{Mr}$. Augustus Raines, Church-street; Mr. J. Sarvis, 1, Cheshire-street; Mr. Thomas Bentley, Friar's Mount; Mr. Joseph Massingham, 4, Green-street. This is to require and request that any parties attended by any of the aforesaid, in the capacity of apothecaries, do forward information thereof to Henry, Blatch, Esq., or to R. Upton, Esq., Apothecaries' Hall, or to H. Pease, Lsq., Secretary to the Protection

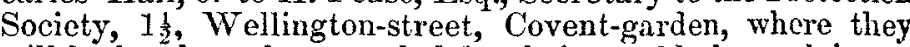
will be handsomely rewarded for their trouble by applying at the office.-N.B. Parties practising illegally, cannot recover any charges by law or otherwise.-God save the Queen."

\section{BREACH OF MEDICAL ETIQUETTE AT NEW. CASTLE.}

To the Ealitor of The LaNCET.

SiR,-Allow me to bring the following case of unprofessional behaviour, on the part of a practitioner in this place, before the notice of your readers:- $A$ woman, named Isabella Crooks, was attended by Mr. Green, an able and experienced surgeon, and died under circumstances which rendered death by an irritant poison probable. Mr. Green, in obedience to the coroner's order, made a post-mortem examination of the body, the result of which he detailed in evidence: he stated that the stomach, which he had ligatured and properly secured, was in his possession, and that owing to his being unaccustomed to chemical analysis, and not having by him the requisite apparatus, he thought the ends of justice would be best served by handing it over to some one well versed in chemistry, and who was also in the habit of conducting such analyses. This proceeding reflects the highest credit on the candour and conscien- 